\title{
The Level of Compliance with International Accounting Standard IAS 18 by Listed Firms in Bahrain
}

\author{
Isa Adnan Budaraj ${ }^{1}$, Adel Mohammed Sarea ${ }^{2}$ \\ ${ }^{1}$ MBA program, Ahlia University of Bahrain, Manama, Kingdom of Bahrain \\ ${ }^{2}$ Accounting and Economics Department, Ahlia University of Bahrain, Manama, Kingdom of Bahrain
}

Email address:

essabudraj@gmail.com (I. A. Budaraj), Adelsarea@hotmail.com (A. M. Sarea)

\section{To cite this article:}

Isa Adnan Budaraj, Adel Mohammed Sarea. The Level of Compliance with International Accounting Standard IAS 18 by Listed Firms in Bahrain. Journal of Investment and Management. Vol. 4, No. 5, 2015, pp. 216-227. doi: 10.11648/j.jim.20150405.22

\begin{abstract}
This Study examines the association between five firm-specific characteristics and the level of compliance with International Accounting Standards (IAS 18) by listed Firms in Bahrain Bourse. A self-constructed compliance checklist was developed and the compliance index was derived to represent the level of compliance among publically traded firms in Bahrain Bourse for the year 2013 to IAS 18 disclosure requirements. The results detected an aggregate mean compliance of $63 \%$ to IAS 18 disclosure requirements. A significant positive relationship was found between the level of compliance and a company's size, and auditor type. A significant negative relationship was found between the IAS 18 disclosure level and a company's debt level (leverage). However, a significant relationship between the level of IAS 18 disclosure level and a company's profits or age could not be established in this research. The results of this research can benefit investors and companies as well, as the results will determine what level of compliance to IAS 18 are listed companies in Bahrain Bourse are committed to, and how transparent are the revenues they are reporting in their financials.
\end{abstract}

Keywords: Corporate Financial Reporting, IAS 18, Disclosure, Bahrain Bourse

\section{Introduction}

The Kingdom of Bahrain is an oil producing island in the Arabian Gulf, and is a member of the GCC (Gulf Cooperation Council). Bahrain was the first country in the Middle East to discover oil in 1932, and with Bahrain achieving its independence in 1971 a high paced growth started, and Bahrain became the region's leading financial center since the 1980s (Bahrain Economic Yearbook, 2013).

The kingdom of Bahrain is populated by more than 1.2 million, with a composition of expats (54\%) and local nationals (56\%). Bahrain's GDP (Gross Domestic Product) stood at \$31 billion (BD11.5 billion), and a \$25 thousand (BD9.3 thousand) GDP per capita. Bahrain's GDP growth rate averaged at 5\% between 2000 and 2012, while inflation stood at 2.8\% year-over-year in 2012. Inflation in Bahrain fluctuated from $2.0 \%$ in 2010 to $-0.4 \%$ in 2011 and then went up again to $2.8 \%$ in 2012 , the reason for such fluctuations was the fall in house prices during the period, and the unfortunate public unrest Bahrain had experienced (Bahrain Economic Year Book, 2013).

Rapid globalization of markets internationally has raised demand for a global standard of comparable financial reporting, harmonizing and standardizing of accounting methods and the manner in which financial information is disclosed is one path to promote a more transparent and consistent financial reporting, thus the International Accounting Standards Board (IASB) devised a set of international accounting standards for publically traded entities around the world (Al-Shammari, et al., 2008).

Currently, all publically traded companies in Bahrain are required to prepare and disclose all their financial statements (annual, semi-annual, and quarterly reports) in compliance with the International Financial Reporting Standards (Tait, D. 2005). By the year 1996, International Accounting Standards compliance was imposed on all publically traded companies in Bahrain (Al-Hussaini, et al., 2008). However, it was not formalized until the issuance of The Bahrain Commercial Companies Law (BCCL) in 2001, which necessitated each publically traded entity to prepare and disclose its statement of financial position (balance sheet), profit and loss report (income statement), statement of cash flows, change in owners' equity, and managers' (directors') report for every financial year before three months pass from the end of the financial year, in 
accordance to IFRS requirements (Tait, D. 2005).

IAS-18 "Revenue" specifies the accounting treatment for when to recognize revenue from the selling of goods, rendering of services, and receiving of interest, dividends, and royalties. The primary issue when accounting for revenues is to determine when to recognize the revenue. The standard was first introduced in 1982 with an effective date of 1984, was revised in 1993, amended in 1998 and 2009, and finally it was decided that IAS 18 will be superseded by IFRS 15 effective from Jan 2017. IAS-18 identifies circumstances when certain criteria, such as the transfer of future economic benefits and the ability to reliably measure those benefits are met and therefore revenue will be recognized (IAS 18).

This research aims to further the findings of other researchers who investigated the level of compliance with IFRS standards in Bahrain and the GCC countries by focusing on one country, Bahrain, and one standard, IAS 18, for the year 2013, and the association between 5 firm specifics, which are size, profitability, leverage, auditor type, and firm age, with the level of compliance. The significance of the study lays in it being in the Kingdom of Bahrain, which is a developing country that has experienced high levels of growth since the discovery of oil, and has a considerable importance both politically and economically. The Kingdom of Bahrain also mandates all publically listed companies to quarterly, semi-annually, and annually, publish their financial statements in compliance with international accounting standards, and that those reports have to be audited by an external independent auditor. This led to a business environment that is highly experienced with international accounting standards reporting.

Though the Kingdom of Bahrain made a public commitment of reaching towards a sole set of high quality international accounting standards through the royal decree no. 21 of the commercial companies' law in 2001, evidence that determines the level of compliance to IFRS in Bahrain remains scant. While previous studies have examined the level of compliance in the GCC such as Al-Shammari (2008) and Mazhar (2002), as well as the level of compliance in Bahrain, such as, Al-Mudhaki (2013), Hamdan (2011), and Ramadhan (2002), those studies are scarce, and each of these studies were not as focused as the current study, targeting all listed companies within one country and measuring the level of compliance with one accounting standard.

The Adoption of IFRS has several benefits, to both investors and companies, such as, the significant increase in the quality of the information communicated to investors, which leads to greater transparency in the companies' financial reporting thus increasing the willingness of investors to provide financing to said companies'. Multinational corporations benefit from having to prepare their statements according to one set of standards rather than multiple, with more than 120 countries adopting IFRS (AICPA, 2015).

The level of compliance is an assurance to investors that the information they are receiving is accurate and dependable, thus the objective of this research is to investigate that level of compliance to IAS 18 in the Kingdom of Bahrain and determine whether the company specific characteristics mentioned earlier, have any influence on the level of compliance with IAS 18.

This research aims to measure the level of compliance of all companies listed on BB to IAS 18. Also the relationship between the five firm specific characteristics being investigated by this research and the level of compliance has been be examined. Therefore the research objectives are:

1) To measure listed companies' in BB level of compliance to IAS 18

2) To investigate the relationship between the level of compliance and the company's size.

3) To investigate the relationship between the level of compliance and the company's Age.

4) To investigate the relationship between the level of compliance and the company's Profitability.

5) To investigate the relationship between the level of compliance and the company's Leverage.

6) To investigate the relationship between the level of compliance and the company's Auditor Type.

The results of this research can benefit investors and companies as well, as the results will determine what level of compliance to IAS 18 are listed companies in Bahrain Bourse are committed to, and how transparent are the revenues they are reporting in their financials. The results can help companies' through the assurance of transparent reporting, which helps attract more investors, as well as reassure current investors and lenders regarding the company's revenue. It can also give an indication regarding the state of the market in Bahrain and the level of sophistication it has reached in disclosure of financial information.

\section{Literature Review}

\subsection{Background of IAS 18}

Income, as defined by the International Accounting Standards Board, is "an increase in economic benefits during the accounting period in the form of a decrease in liabilities or in the form of an inflow or enhancements of assets that results in an increase in equity". It comprises of both revenues and gains. Revenue is income that is realized through the ordinary activities of the company (sales, fees, royalties,.. etc.), while a gain is the result of a peripheral activity, such as the sale of company equipment for a price higher than the book value, the excess is realized as gains (IAS 18, 2009).

The goal of IAS 18 is to describe the accounting methods related to revenues realized from certain types of events and transactions. The primary issue when accounting for revenues is to determine when to recognize revenue. As prescribed in IAS 18 "revenue is recognized when the future economic benefits are probable to flow into the entity, and the ability to measure those benefits is reliable" (IAS 18, 2009). 
Since its introduction in 1982 the standard has been amended several times, until it was finally decided that IAS 18 will be superseded by IFRS 15 effective from Jan 2017 (IASPlus, Deloitte). IAS 18 applies to the accounting for revenue generated from the sale of goods, rendering of services, interest income, royalties, and dividends (IAS 18, 2009).

\subsection{The Need of IAS 18}

Revenue is usually one of the biggest items in the financial statements. Revenue manipulation was the center of several high profile financial statements fraud in recent years. If financial statements are to fairly and accurately reflect the true economic activities of an entity, a consistent approach to revenue recognition is substantially important (Kelly, 2014).

According to the conceptual framework of financial reporting, financial statements are prepared under the accruals basis of accounting assumption, which matches costs with the revenues they generate. The timing of revenue recognition is crucial to appropriately match costs with revenues in the correct period. The calculation method of revenues is essential to any meaningful understanding of an entity's financial performance. Revenue is generally recognized at the point of sale, because four criteria will have been met at that point, which are:

1. The buyer has been provided with the product or service.

2. The liability to pay the seller for goods and services provided has been recognized by the buyer.

3. The willingness indicated by the buyer to settle the obligation.

4. The establishment of the monetary value of goods and services provided.

Because many investors use the growth in revenues as a key performance indicator, and the direct impact it has on earnings, management may be tempted to manipulate revenues, either overstating them to attract more investors and raise stock price, or understating them to reduce the amount of taxes paid. Either ways, it is the duty of a Certified Public Accountant (CPA) to examine the statements prepared by the public company and confirm that revenues have been prepared in accordance to International Accounting Standards (Kelly, 2014).

Growing firms with ample opportunities generally have fewer established assets, thus they are compelled to exhibit a higher quality of reporting, such as recognizing losses more timely than a firm that is less conservative. Growth opportunities also provide greater discretion to managers on the timing in which to recognize expenses and revenues, thus increasing the potential for earnings management. Further, the increase in the amount of foreign investments will lead to greater separation of ownership and management, a separation like this can result in an agency problem that is also linked to the financial reporting quality (Rosa \& Tiras, 2013).

\subsection{IFRS Adoption}

The development of the international accounting standards began decades ago in an attempt by developed countries to create accounting standards that small developing countries that lack the resources to create their own accounting standards can use. But since then, and with the globalization of the business world, investors, international companies, auditors, and regulators started to realize the increased significance of implementing a common set of accounting standards in all areas of the reporting chain of financial information (AICPA, 2011).

A year after the establishment of the International Accounting Standards Board (IASB) in 2001, European Union members committed to impose a mandatory compliance to IFRS on public corporations in its jurisdiction, with an effective date of 2005 (Rammana \& Sletten, 2009).

The IASC set and established minimum disclosure guidelines, which companies, in countries mandating IAS compliance, were required to follow. However, the International Accounting Standards Committee (IASC) as well as the International Federation of Accountants (IFAC) were concerned that many companies were alleging compliance to IAS requirements, while in fact they were not complying with all the IAS's requirements. Prior researches by Street et al., Cairns, and Saleem supported the concerns of the IFAC and the IASC by bringing to light evidence that the level of compliance is very mixed and somewhat selective for companies alleging full compliance to IAS requirements (Joshi \& Al-Mudhahki, 2013).

More than one hundred and forty countries, including all European countries, required or permitted the use of International Accounting Standards for financial reporting by 2015. Approximately $85 \%$ of those countries mandate the use of IFRS for the preparation of financial reports by local publicly traded companies (SEC, 2008). The United States however, is still using a domestic standard, GAAP (Generally Accepted Accounting Principles), although support for a single set of high quality globally accepted accounting standards is growing, but support for the adoption of IFRS does not exist (IASPlus, 2015)

In 1983 both national and international leading accounting firms in Bahrain were invited by the Ministry of Trade and Agriculture to enter a newly established committee that was tasked with the setting of accounting standards in Bahrain. The decision as to whether International Accounting Standards should be used as Bahrain's national accounting standard was left to the committee. The committee recommended that except for IAS 15 (Information reflecting the effects of changing prices); all International Accounting Standards are to be adopted in Bahrain (Al-Qahtani, 2005).

\subsubsection{IFRS Adoption in Developing Countries}

Emerging markets can be defined as low income countries that are experiencing rapid growth using economic liberalization as their engine for growth. Those countries are classified as either developing countries in Asia, Latin America, the Middle East, and the African continent, or economies in transition such as China (Broker, 2012).

First we need to identify the reason why developing 
countries use IFRS for financial reporting? For some countries, it is due to pressure imposed on them by large international corporations or the World Bank, while for others it is the desire to attract financial resources and promote their development. Cooke and Wallace (1990) found that the level of regulations for financial information disclosure for corporations in several developed nations probably results from internal factors, such as the legal rules of the country, the level of economic development, and the implicit and explicit objectives of society (Albu et al., 2011).

The World Bank, the International Federation of Stock Exchanges (IFSE), the International Organization for Securities Commissions (IOSCO), and the IASC believe that adopting IAS's is appropriate for developing countries, the most mentioned reasons being: reducing the production cost and set up cost of their own accounting standards, improving their level of accounting, and joining the international harmonization drive (Joshi \& Al-Mudhahki 2013).

A Study examining the level of compliance in Egypt to IAS 12 "Income Tax" found a low level of compliance, especially for companies audited by local auditing firms (Ebrahim, 2014). Another study in Ghana examined the level of IFRS compliance for companies publically traded on the Ghana Stock Exchange (GSE). An overall mean compliance rate of $85.8 \%$ was revealed by the study, with a $62.2 \%$ minimum compliance rate and an $85.8 \%$ maximum compliance rate (Yiadom \& Atsunyo, 2014).

\subsubsection{IFRS Adoption in Developed Counties}

The first two years of adoption for Europe were difficult, as the transition from local standards to international standards required developing new information and accounting systems, train staff, and deal with managers who were not motivated for the change. However, the transition had a positive impact on earnings, as managers were less motivated to manipulate accounting numbers to increase earnings (Boumediene et al., 2014).

In late 2008 the Securities and Exchange Commission (SEC) released a proposal entitled "Roadmap for the Potential Use of Financial Statements Prepared in Accordance with International Financial Reporting Standards by U.S. Issuers". The proposal was to force publically traded corporates in the U.S. to start implementing IFRS by the end of 2014, 2015, or 2016 (Harper et al., 2012). However, Fitch Ratings stated in a report that the probability of IFRS being fully adopted in the United States in the specified time period is growing less likely due to the IASB and the FASB (Financial Accounting Standards Board) moving further away from full convergence of their standards (Bramwell, J. 2014).

A study conducted in Turkey in the year 2011 examined the level of compliance of companies listed on the Istanbul Stock Exchange, a total of 168 companies, the results showed a level of compliance of 0.79 , which is lower than Australia (0.94), Germany (0.81), and the GCC countries
(0.82) (Demir \& Bahadir, 2014).

\subsubsection{IFRS Adoption in Bahrain}

Since 1997, the representatives of twenty two Arab countries issued a recommendation during a forum in Dubai to support the use of IAS before 1998. Bahrain never developed its own domestic accounting standards due to the following reasons:

- Bahrain being an international financial center;

- A large number of foreign banks operates in Bahrain, those banks follow international standards as they are considered benchmarks for comparison, and

- Bahrain is a small country with a small population, the required expertise to develop a local standard was limited, or it might have been too expensive to develop a local standard (Joshi \& Al-Mudhahki, 2013).

Since 1992 financial year-end, the Central Bank of Bahrain (formerly known as the Bahrain Monetary Agency) required all banks to produce their financial reports in accordance with IAS, and those statements must be audited by an external auditor (Hussain \& Isalm, 2002).

Currently, all publically traded companies operating in Bahrain are mandated to prepare their financial reports in compliance with the International Financial Reporting Standards requirements (Tait, 2005). By 1996 all public companies listed on $\mathrm{BB}$ were required to follow the requirements of IAS in the preparation of disclosed financials (Al-Hussaini et al., 2008). In 2001 every registered company in Bahrain was mandated to produce an audited Income Statement, Statement of Financial Position, and the directors' report for the previous financial year within the first quarter of the new financial year, in compliance with all IFRS requirements (Tait, 2005).

\subsection{Company Characteristics and the Level of Compliance}

The level of firm IFRS compliance varies according to several firm specific characteristics. One of those characteristics is firm size, as it is argued that to protect their name and reputation, as well as to avoid government intervention; larger companies will have a higher degree of compliance than smaller ones. The agency theory supports such argument that larger firms are assumed to have a higher level of compliance with accounting standards, as larger firms have higher agency costs due to a more complicated organizational framework, disclosure is used to reduce information asymmetry amidst the company's management (insiders) and equity providers (outsiders) (Demir \& Bahadi, 2014).

Another firm specific characteristic supported by the agency theory with the level of accounting standard compliance is auditor type. External auditors are viewed as a mechanism that helps reduce the conflict between shareholders and managers interests. Large audit firms are argued to reduce agency costs by exerting a more monitoring role and limiting managers' opportunistic behavior (Yiadom \& Atsunyo, 2014).

Profitability is another firm specific characteristic linked 
with the level of compliance. As per the signaling theory, it is assumed that managers of more profitable companies wish to signal their strength and success to current and potential investors. Managers in profitable companies also wish to justify their positions and packages, thus are more probable to disclose higher quality of information than companies with lower profits (Demir \& Bahadir, 2014).

Agency theory also associated a company's leverage with the level of accounting standard compliance, as companies with high leverage are assumed to disclose more and higher quality information in order to reduce agency cost. High leverage companies, by definition, have lesser equity and are subject to equity risk, therefore, the demand by shareholders for information increases as they need to assess whether the company will be able to meet its financial debt obligations and the risk of future cash flows associated with their investment (Al-Shammari et al., 2008).

The last firm specific characteristic this research will investigate is the age of the company. It is argued that companies who have been operating in the market longer than others disclose more information; this argument is supported by several factors, such as older companies being most likely well established and in possession of professional, well trained, staff in charge of preparing the financial statements. Older firms are also more likely to have a more established accounting system capable of meeting detailed IFRS requirements. It is also argued that while older firms seek to enhance their image and reputation in the market, complying with disclosure requirements is more likely than younger firms who might not disclose full information because disclosing sensitive information to established competitors might be harmful (Demir \& Bahadir, 2014). Thus it can be said that the signaling theory is in support of the relationship between the age of the company and the level of disclosure requirement compliance.

\subsection{Challenges in Implementing IAS 18}

Implementation of IFRS and IAS can have certain challenges, especially in emerging markets, such as resistance to change, the lack of educated and trained professionals, resources, and the reduced power of internal coercive factors (Albu et al., 2011). The movement towards the international harmonization of financial reporting, which would eventually lead to symmetry in accounting standards, can come into struggle with some objectives of financial reports, as well as, more fundamentally, social, economic, and cultural contexts of different accounting systems, and even to some extent, with national sovereignty (Karim, 2001). IAS 18 has been specifically criticized for being vague, leading to inconsistencies when applied in practice. IAS 11, which deals with revenues and costs from construction contracts, has also been criticized as there has been uncertainty about which standard to use, IAS 18 or IAS 11, in some cases. The timing of revenue recognition is a challenge facing the implementation of IAS 18 as some companies lack a clear and comprehensive understanding of IAS 18, this is evident in the case of goods and services, as services are provided over a period of time while goods are sold at a point in time (Kelly, 2014).

\subsection{Hypothesis Development}

The hypothesis of this study has measured the relationship between the level of compliance with IAS 18 "Revenue" and the 5 firm specific characteristics mentioned earlier, which were chosen based on previous studies.

1) Firm Size: Many researchers, such as Watts and Zimmerman (1978) and Holthausen and Leftwich (1983) found that larger firms have a higher level of compliance with IFRS disclosures due to the reputational risk and their need to attract viable investments. Hossain and Hammami (2009), Juhmani (2012), and Al-Shammari and Al Sultan (2010) found a positive link between the quality of financial information reported by public firms and firms size. However, Demir and Bahadir (2014), and Glaum and Street (2003) failed to find a relationship between firm compliance to IFRS and firm size.

Hence, based on prior studies, this research hypothesizes:

H0: There is no significant relationship between firm size and IAS 18 compliance.

H1: There is a significant relationship between firm size and IAS 18 compliance

2) Firm Age: Literature on firm age and IFRS disclosure show mixed results, Hossain and Hammami (2009) and Al-Shammari (2011) found a positive relationship between IFRS disclosure and firm age based on the argument that older firms are more exposed to the business cycle and have a stronger will to protect their reputation, as well as their ability to hire competent and professional staff who can produce reports in line with IFRS disclosure requirements. However, Glaum and Street (2003), Alsaeed (2006), and Juhmani (2012) found no association between firm age and level of IFRS compliance. Hence this research hypothesizes:

H0: There is no significant relationship between firm age and IAS 18 compliance.

H1: There is a significant relationship between firm age and IAS 18 compliance.

3) Profitability: Prior studies such Street and Bryant (2000), Hossain and Hammami (2009) failed to find an association between profitability and the firms level of compliance with IFRS disclosures. Similarly, AlSaeed (2006), Glaum and Street (2003), and Juhmani (2012) found that profitability is not significantly associated with the level IFRS disclosure compliance. However, there are some, such as Wallace et al (1994) and Agyei-Mensah (2014) who found a positive relationship between profitability and the level of disclosure compliance. Some theories, such as the signaling theory, indicate that profitable firms' management will seek to take advantage of benefits associated with quality reporting to share their success with current and prospective shareholders and 
investors. Hence, based on the prior argument, this research hypothesizes:

H0: There is no significant relationship between firm profitability and IAS 18 compliance.

H1: There is a significant relationship between firm profitability and IAS 18 compliance.

4) Leverage: A high leverage ratio may result in difficulty when attracting additional funds from creditors or prospective investors; hence many firms reduce the shareholder-debt holder conflict through providing high quality financial reports by complying with IAS/IFRS requirements (Al-Shammari, 2011). However, Demir and Bahadir (2014) found a negative relationship between the quality of financial report and leverage. Also, Alsaeed (2006), Ali et al (2004), and Juhmani (2012) reported an insignificant relationship between leverage and the level of compliance with IFRS.

To further examine the relation between IFRS compliance and leverage, this research hypothesizes:

H0: There is no significant relationship between firm leverage and IAS 18 compliance.

H1: There is a significant relationship between firm leverage and IAS 18 compliance.

5) Auditor Type: The level of compliance with IFRS has been linked with the type of auditor, for example, Demir and Bahadir (2014) found a positive association between firms audited by one of the big four auditing firms and the level of IFRS disclosure compliance.
Even though Hossain et al's (1995) New Zealand study could not find a significant relationship between auditor type and the level of compliance, it is widely accepted that all big four auditing firms value their brand name highly and will not fall under their clients' pressure, while encouraging them to comply with IFRS mandatory disclosure requirements. Based on the previous argument, this research hypothesizes:

H0: There is no significant relationship between firm's auditor type and IAS 18 compliance.

H1: There is a significant relationship between firm's auditor type and IAS 18 compliance.

\section{Research Methodology}

\subsection{Sample Selection}

The population of this research consists of the publically listed commercial banks, investment banks, insurance companies, services companies, hotels and tourism companies, industrial companies, and non-Bahraini companies listed on the Bahrain Bourse. The total number of listed companies on the bourse was 47 companies in 2013, which included 2 closed companies and 3 suspended companies which were excluded from the sample. Another 6 companies were excluded from this research as their financials were not available. Excluded companies and the reason for their exclusion can be seen in Table 1. The final sample thus is 36 listed companies from the Bahrain Bourse.

Table 1. Excluded Companies.

\begin{tabular}{ll}
\hline Company: & Reason \\
\hline 1. Securities and Investment Company & Closed Company \\
2. United Paper Industries & Closed Company \\
3. Gulf Monetary Agency & Suspended \\
4. Taib Bank & Suspended \\
5. Global Investment House & Suspended \\
6. United Gulf Investment Corp. & No published audited financial reports \\
7. Bahrain Car Park Company & No published audited financial reports \\
8. Bahrain Ship Repairing \& Engineering & No published audited financial reports \\
9. Banader Hotels Company & No published audited financial reports \\
10. International Investment Group & No published audited financial reports \\
11. United Finance Company & No published audited financial reports \\
\hline
\end{tabular}

\subsection{Measurement of the Dependent Variable}

As mentioned earlier, the dependent variable in this research is the level of IAS 18 disclosure compliance. The level of compliance has been measured through a selfconstructed compliance index (CINDEX) similar to prior compliance measurement studies, such as Yiadom \& Atsunyo (2014). The compliance index ratio measured what each company presented and disclosed in its end of year audited financials, to what each company is obligated to present and disclose as per IAS 18. The checklist was constructed using paragraphs from the IAS18 standard, when a company is in compliance with the requirements of a paragraph a dummy variable " $1 "$ was assigned in the checklist, while noncompliance was assigned a " 2 ", and if the requirement is not applicable for the company, such as exchange of goods or royalties disclosure which is not practiced by all companies, a "3" was assigned on the checklist. The Dichotomous method was used to determine the level of company compliance to IAS18 requirements, where a company is either in compliance with IAS 18 requirements or isn't, if the requirement is not applicable to the company, the company will not be penalized for it. The IAS18 Compliance Index was then computed using SPSS.

\subsection{Measurement of the Independent Variables}

Five company specific characteristics were examined in order to investigate if those characteristics had any impact on the level of compliance to IAS 18. The five characteristics and their measurements are as follows: 


\section{a. Company Size}

The natural logarithm of each company's total assets was used to measure the company's size. This method was used in prior studies such as Yiadom \& Atsunyo (2014) and Al Shammari (2008)

b. Company Profitability

The company's' profitability was measured by each company's Return on Equity (ROE), which is the company's net profit divided by its total equity. This method was previously used by Demir \& Bahadir (2014)

c. Company Leverage

Each Company's leverage ratio was calculated by dividing the total amount of debt by the company's total equity (debt to equity ratio). This measurement was used in previous studies such as Al-Shammari et al. (2008).

d. Company Auditor Type

Company's audited by big four audit firms were assigned a dummy variable " 1 ", while company's audited by other auditing firms were assigned a dummy variable of " 2 ". This method was previously used by Yiadom and Atsunyo (2014).

e. Company Age

The number of years since the company was founded.

\subsection{Model Development}

In order to determine the effect on the level of IAS18 compliance each company characteristic has on the sample companies listed on the Bahrain Bourse the following multiple linear regression model was developed:

$$
\begin{gathered}
\text { Cindex }=\beta_{1}+\beta_{2} \text { CSize }+\beta_{3} \text { CAge }+\beta_{4} \text { CProfit }+\beta_{5} \text { CLevrg }+ \\
\beta_{6} \text { CAudit }+\varepsilon i \ldots \ldots
\end{gathered}
$$

Where:

$$
\begin{gathered}
\text { Cindex }=\text { Compliance Index; } \\
\text { CSize = Log of total assets; } \\
\text { CAge = Company age; }
\end{gathered}
$$

$$
\begin{gathered}
\text { CProfit = Company's return on equity; } \\
\text { CLevrg = Debt to equity ratio; } \\
\text { CAudit = Company's auditor type; } \\
\varepsilon i=\text { Random error. }
\end{gathered}
$$

\section{Data Analysis and Discussion}

\subsection{Descriptive Statistics}

The mean of the disclosure compliance level with IAS 18 for the sample companies was $63 \%$ with a maximum of $100 \%$ and a minimum of $14 \%$ (per IAS18 disclosure requirements). The results are lower than the total IFRS disclosure level in some developed countries such as Australia (0.94, Tower et al, 1999), Germany (0.81, Glaum \& Street, 2003), Turkey (0.79, Demir \& Bahadir, 2014), and Switzerland (0.74, Street \& Gray, 2002), however, these results are higher than some neighboring countries such as Saudi Arabia (0.33, Alsaeed, 2006), Jordan (0.63, Naser, 1998), and Bangladesh (0.44, Akhtaruddin, 2005). A study published by Al-Shammari et al (2008) measured the total level of IFRS compliance in the GCC, the disclosure mean was 0.82 , with the U.A.E being the highest $(0.85)$ and Qatar the lowest (0.71), while Bahrain scored a total compliance mean of 0.82 . This would indicate that the disclosure for IAS18 is below average in Bahrain compared to other standards. It is also worth mentioning that the results indicate a level of compliance to one standard (IAS 18) while the comparable results are for an overall level of

\begin{tabular}{|c|c|c|c|c|c|}
\hline & Mean & Median & Max. & Min. & Std. Dev. \\
\hline \multicolumn{6}{|l|}{ Dependent Variable } \\
\hline IAS18 Compliance & 0.63 & 0.704 & 1 & 0.139 & 0.303 \\
\hline \multicolumn{6}{|l|}{ Independent Variables } \\
\hline Company Size (Ln) & 12.422 & 11.695 & 16.326 & 8.691 & 2.031 \\
\hline Company Age & 28.056 & 31.5 & 56 & 3 & 13.469 \\
\hline Company Profitability (ROE) & 0.066 & 0.071 & 0.222 & -0.192 & 0.092 \\
\hline Company Auditor Type & 0.833 & 1 & 1 & 0 & 0.378 \\
\hline
\end{tabular}
compliance to all IASs. Companies listed on the Bahrain Bourse ranged in size (total assets) from BD12 billion (Ahli United) to BD6 million (Bahrain Family Leisure Company, with a mean of BD1.5 billion. The size distribution was skewed; the natural logarithm was utilized to mitigate the skewness in the regression analysis, which is consistent with prior studies (Demir \& Bahadir, 2014).

Table 2. Descriptive Statistics.

Company age had an average of 28 years, and ranged from 56 year old companies, to only 3 year old companies. National Bank of Bahrain is the oldest listed company in Bahrain, and the first national bank to start operations in the Island. While Ithmaar bank is not relatively new to the market, it is considered so due to it merging with its subsidiary (Shamil Bank) in 2010 to form a new Islamic banking entity.
The sample leverage ratio ranged from 0 to 10.65 , with an average of 2.13. This would indicate that while some companies had no debt at all, others were heavily leveraged. The high leverage ratio is to be expected as the biggest component of the sample being commercial and investment banks. Auditor type was simply categorized as big four (1) and non-big four (2). The results show that around $83 \%(30$ of the 36 companies in the sample) of the listed companies in 
Bahrain are audited by a big four firm.

\subsection{Empirical Analysis and Testing of Hypothesis}

As previously mentioned in chapter1, these are the hypothesis of this research:

1. $\mathrm{H}_{0}$ : There is no significant relationship between firm size and IAS 18 compliance.

$\mathrm{H}_{1}$ : There is a significant relationship between firm size and IAS 18 compliance

2. $\mathrm{H}_{0}$ : There is no significant relationship between firm age and IAS 18 compliance.

$\mathrm{H}_{1}$ : There is a significant relationship between firm age and IAS 18 compliance.

3. $\mathrm{H}_{0}$ : There is no significant relationship between firm profitability and IAS 18 compliance.

$\mathrm{H}_{1}$ : There is a significant relationship between firm profitability and IAS 18 compliance.

4. $\mathrm{H}_{0}$ : There is no significant relationship between firm leverage and IAS 18 compliance.

$\mathrm{H}_{1}$ : There is a significant relationship between firm leverage and IAS 18 compliance.

5. $\mathrm{H}_{0}$ : There is no significant relationship between firm's auditor type and IAS 18 compliance.

$\mathrm{H}_{1}$ : There is a significant relationship between firm's auditor type and IAS 18 compliance.

The aim of these hypotheses is to determine if the independent variables being tested in this research (Company size, age, profitability, leverage, and auditor type) have any effect on the company's IAS18 disclosure level.

As shown below in table 4.4, the resulted $\mathrm{R}$ appears to be $22.10 \%$ which signifies a weak correlation as per the Cohen (1998) guidelines for the interpretation of correlations. The level of impact the independent variables have on IAS18 compliance (R-square) is around $5 \%$ which is also a weak percentage. The resulted $p$-value is 0.001466 which is less than 0.05 , and the F-test value of 4.277 determines that the study model is acceptable.

Table 3. Testing of Hypothesis.

\begin{tabular}{lll}
\hline Variables & t.test & Sig. \\
\hline Company Size & 2.436 & 0.006 \\
Company Age & -0.230 & 0.820 \\
Company Profits & 0.557 & 0.582 \\
Company Leverage & -2.180 & 0.019 \\
Company Auditor Type & 1.978 & 0.038 \\
R & 0.221 & \\
R-Square & 0.049 & \\
F-Test & 4.278 & \\
$p$-value (f-statistics) & 0.001466 & \\
\hline
\end{tabular}

\subsubsection{Company Size}

As mentioned previously, the agency theory supports the argument that larger companies are assumed to have a higher level of compliance, as they will act to protect their market standing, reputation, and name. The research results show that there is a positive significant relationship between firm size and level of IAS18 compliance, as Sig. $<0$. This is in compliance with previous researches done by Juhmani
(2012), Hossain and Hammami (2009), and Al Shammari and Al-Sultan (2010). Thus the alternative hypothesis is chosen

\subsubsection{Company Age}

This research assumed that due to older firms being well established and having the possession of professional and well trained staff in charge of the preparation of the financial statements, a significant positive relationship should exist. Also, the signaling theory supports the relationship between firm age and level of compliance due to some newer firms choosing not to disclose sensitive information to their older, well established competitors. However, the research results conclude that there is no significant relationship between firm age and level of compliance due to the Sig. $>0.05$. The lack of a significant relationship is in compliance with previous research results done by Juhmani (2012), Glaum and Street (2003), and Alsaeed (2006). The null hypothesis is accepted due to the lack of a significant relationship between the level of compliance and firm age.

\subsubsection{Company Profits}

The hypothesis supporting a significant positive relationship between the level of compliance and the level of profits was supported by this research. The signaling theory also supports the existence of a relationship between the level of compliance and the firm's profits on the basis that as managers in profitable companies wish to disclose accurately their performance to justify their positions and packages. However, this study found no significant relationship between the level of compliance and the firms' profits level, with a Sig. $>0.05$. This result is in compliance with prior results of Street and Gray (2001), Street and Bryant (2000) and Hossain and Hammami (2009). The null hypothesis is accepted due to the lack of a significant relationship between the dependent and independent variables.

\subsubsection{Company Leverage}

This research was in support of a significant positive relationship between a firm's compliance level and leverage ratio. Agency theory also supports the argument that highly leveraged firms' have to disclose more information to satisfy shareholder demands. The access to credit lines also depends on the availability of information regarding the firm so that credit lenders can do proper risk analysis. The results of the research however found a negative significant relationship between the level of compliance and a firm's leverage with a Sig. $<0.05$. The negative relationship might be due to highly leveraged firms trying to present a better picture of the firm's performance. This result is in compliance with prior researches such as Demir and Bahadir (2014). The alternative hypothesis is accepted here, regardless of the direction of the relationship, as a significant one does exist between the dependent and independent variables.

\subsubsection{Company Auditor Type}

A general assumption is that firms audited by one of the big four audit firms is expected to have a higher level of compliance, that being due to the inability of a firm to 
practice contract pressure on one of the big four audit firms, who value their reputation and firm image more than a single contract from one firm. As expected, the results of the analysis found a significant positive relationship between a firm's level of compliance and the type of auditor responsible for auditing its financials with a Sig. $<0.05$. This result is in compliance with prior researches such as Demir and Bahadir (2014). The alternative hypothesis is accepted due to the presence of a significant relationship between the dependent and independent variables.

Table 4. Hypothesis Results.

\begin{tabular}{lll}
\hline Hypothesis & Expected Results & Actual Results \\
\hline $\begin{array}{l}\text { 1. A significant relationship exists between company size and level } \\
\text { of IAS } 18 \text { compliance }\end{array}$ & Significant positive relationship & There is a significant positive relationship \\
$\begin{array}{l}\text { 2. A significant relationship exists between company age and level } \\
\text { of IAS } 18 \text { compliance }\end{array}$ & Significant positive relationship & No significant relationship \\
$\begin{array}{l}\text { 3. A significant relationship exists between company profitability } \\
\text { and level of IAS } 18 \text { compliance }\end{array}$ & Significant positive relationship & No significant relationship \\
$\begin{array}{l}\text { 4. A significant relationship exists between company leverage and } \\
\text { level of IAS } 18 \text { compliance }\end{array}$ & Significant positive relationship & There is a significant negative relationship \\
$\begin{array}{l}\text { 5. A significant relationship exists between company auditor type } \\
\text { and level of IAS } 18 \text { compliance }\end{array}$ & Significant positive relationship & There is a significant positive relationship
\end{tabular}

\section{Conclusion}

\subsection{Conclusion}

This research examined the extent of disclosure compliance with IAS18 by 36 companies listed on the Bahrain Bourse for the year 2013. Five company specific characteristics were measured for the level of influence they had on the company's level of IAS18 disclosure compliance. A compliance index was derived from a self-constructed checklist which represented the average compliance to IAS18 among the selected sample companies. Multiple regression analysis was used, after validating the data gathered in the checklist, to measure the level of relation the level of IAS18 compliance had with the five selected company characteristics. The five company specific characteristics examined in this research were company size, company age, company profitability, company leverage, and company auditor type. The reason behind choosing those characteristics is that they proved to have a significant influence on the level of accounting standard disclosure compliance as per prior studies, such as Al-Shammari (2008) and Yiadom \& Atsunyo (2014).

The level of disclosure varied among companies, for there were some companies that settled for a small paragraph no longer than a few sentences to sum up its revenue recognition criteria, whiles others disclosed their treatment of revenues in a much more detailed manner. This caused the level of disclosure compliance among companies to vary, and hence the company characteristics were examined if they had any influence on the level of disclosure. The results show that there is a significant positive relationship between the level of IAS18 disclosure and a company's size, a company's auditor type, as well as a significant negative relationship between a company's leverage level and IAS18 disclosure compliance. However, this research found no significant relationship between the level of disclosure compliance and a company's age or profits. The level of disclosure compliance was $63 \%$, which is low considering that prior studies (Juhmani, 2012) found that the overall disclosure compliance in Bahrain to IFRS requirements was $81 \%$. This would indicate that some standards have a high level of compliance while others have a low level of compliance.

\subsection{Implications and Contributions}

This level of IAS 18 disclosure compliance among Bahraini listed companies was lower than expected, at $63 \%$, compared to the overall level of compliance to the IAS's and IFRS disclosure requirements, which was measured at $81 \%$ by Juhmani (2012). This would indicated that the regulator's nationwide monitoring and enforcement mechanisms need to be improved, as Revenue, as mentioned previously in the research, is usually the biggest item in the financials of a company, and is prone to tampering to reflect an adjusted image of a company's performance.

\subsection{Limitations and Future Research}

This research had some limitations, as with any research. The biggest limitation of this study was the small sample size which was due to the limited size of the Bahraini economy and the small number of listed companies on the Bahrain Bourse. The already small sample size was reduced further due to some companies being suspended, closed, or do not have any audited published financials. Another major limitation of this study was the absence of a criterion to reflect the level of importance of each disclosure requirement to financial statements users. In this research all IAS18 disclosure requirements were treated equally, which might not give an accurate picture.

Another limitation of the study is the use of certain ratios, such as the leverage ratio (debt to equity) and the return on equity ratio to measure profitability (net income divided by total equity). The results of this research might have varied if different ratios have been used, such as debt to assets ratio to measure leverage, or return on assets to measure profitability. Finally, a limitation to this research was the scarcity of similar researches to compare results with, as 
most researches done in the region were to measure overall level of compliance and not the level of compliance to a certain standard alone.

As mentioned earlier, one of the major limitations to this research was the small size of its sample, so increasing the sample size by measuring the level of compliance among GCC countries for example is a recommended step. Another suggestion would be to develop a compliance index that takes into consideration the degree of importance each disclosure requirement has, and whether the requirement is a financial one or a non-financial one. Finally, it is also recommended to take into consideration other company specific characteristic which might influence the level of disclosure compliance, such as dual-listing, internationality, and ownership concentration.

Appendix 1. Disclosure Compliance Checklist for IAS 18.

Presentation/Disclosure Requirement

\begin{tabular}{|c|c|}
\hline & Presentation/Disclosure Requirement \\
\hline 1 & $\begin{array}{l}\text { The entity disclosed the accounting policies adopted for the recognition of revenue, including the methods adopted to determine the stage of } \\
\text { completion of transactions involving the rendering of services. }\end{array}$ \\
\hline & The entity disclosed the amount of each significant category of revenue recognized during the period, including revenue arising from: \\
\hline 2 & 1) Sale of Goods \\
\hline 3 & 2) Rendering of services \\
\hline 4 & 3) Interest \\
\hline 5 & 4) Royalties \\
\hline 7 & Disclosure of contingent assets \\
\hline 8 & Disclosure of contingent liabilities \\
\hline 9 & Revenue is measured at the fair value of the consideration received or receivable \\
\hline 10 & $\begin{array}{l}\text { Measurement of the fair value of the consideration received or receivable takes into account the amount of any trade discounts and volume } \\
\text { rebates allowed by the entity }\end{array}$ \\
\hline 11 & Deferred payment by a customer/client constitues a financing transaction \\
\hline 12 & Fair value is determined by discounting all future receipts using an imputed rate of interest for financing transactions \\
\hline 13 & The entity did not recognize the exchange of similar goods or services as revenue. \\
\hline 15 & $\begin{array}{l}\text { The entity measured the revenue generated from the exchange of dissimilar goods or services at the fair value of the goods or services } \\
\text { received. }\end{array}$ \\
\hline 16 & $\begin{array}{l}\text { Transactions include different separately identifiable components when the entity enters into transactions that comprise more than one } \\
\text { component (e.g. delivery of both goods and services, delivery of a number of different goods or services). } \\
\text { revenue from the sale of goods is recognized when all of the following conditions have been satisfied: }\end{array}$ \\
\hline 17 & a) The entity has transferred to the buyer the significant risks and rewards of ownership of the goods \\
\hline 18 & $\begin{array}{l}\text { b) The entity retains neither continuing managerial involvement to the degree usually associated with ownership nor effective control over } \\
\text { the goods sold }\end{array}$ \\
\hline 19 & c) The amount of revenue can be measured reliably \\
\hline 20 & e) It is probable that the economic benefits associated with the transaction will flow to the entity \\
\hline 21 & f) The costs incurred or to be incurred in respect of the transaction can be measured reliably \\
\hline 22 & The entity did not retain significant risks and rewards of ownership of the goods \\
\hline 23 & $\begin{array}{l}\text { The entity retained only an insignificant risk of ownership, and the transaction accounted for a sale and revenue has been recognized (Sale } \\
\text { of goods). }\end{array}$ \\
\hline 24 & There is no uncertainty regarding the collectability of an amount already included in revenue \\
\hline 26 & Expenses that relate to the revenue transaction can be measured reliably \\
\hline 27 & Revenue involving the rendering of services is recognized only when the outcome of the transaction can be estimated reliably \\
\hline 28 & $\begin{array}{l}\text { Revenue associated with the service transaction is recognized by reference to the stage of completion of the transaction at the end of the } \\
\text { reporting period (often referred to as the percentage of completion method) }\end{array}$ \\
\hline 29 & $\begin{array}{l}\text { The percentage of completion of the service transactions is determined by using a method that reliably measures the proportion of service } \\
\text { actually performed }\end{array}$ \\
\hline 30 & $\begin{array}{l}\text { Revenue has been recognized on a straight line basis over the specified period (unless some other method better represents the stage of } \\
\text { completion) }\end{array}$ \\
\hline 31 & $\begin{array}{l}\text { When the outcome of a service cannot be estimated reliably, revenue will only be recognized to the extent of recognized costs that are } \\
\text { recoverable. }\end{array}$ \\
\hline 32 & $\begin{array}{l}\text { When the outcome of a service cannot be estimated reliably and it is not probable that the costs incurred will be recovered, revenue is not } \\
\text { recognized and the costs incurred are recognized as expenses. }\end{array}$ \\
\hline & Revenue in the form of interest, royalties or dividends, recognized only when both of the following conditions are satisfied: \\
\hline 33 & It is probable that the economic benefits associated with the transaction will flow to the entity \\
\hline 34 & The amount of the revenue can be measured reliably \\
\hline & Revenue recognized on the following bases: \\
\hline 35 & 1) Interest: using the effective interest rate method as set out in IAS 39 \\
\hline 36 & 2) Royalties: on an accrual basis in accordance with the substance of the relevant agreement \\
\hline 37 & 3) Dividends: when the shareholder's right to receive payment is established \\
\hline 38 & When entering into agreements for the construction of real estate, the entity will apply IAS 11 rather than IAS 18 . \\
\hline
\end{tabular}




\section{References}

[1] A Closer Look at the New Revenue Recognition Standard. (2014). Earnest and Young. (http://www.ey.com/Publication/vwLUAssets/Applying_IFRS :_A_closer_look_at the_new_revenue_recognition_standard_ (June_2014)/\$FILE/Applying-Rev-June2014.pdf)

[2] Agyei-Mensah, B.K. (2014). Adoption of International Financial Reporting Standards (IFRS) in Ghana and the Quality of Financial Statement Disclosures. International Journal of Accounting and Financial Reporting, 3(2), 269-282.

[3] Akhtaruddin, M. (2005). Corporate Mandatory Disclosure Practices in Bangladesh. The International Journal of Accounting, 40(4), 399-422.

[4] Albu, N., Nicolae-Albu, C., Bunea, S., Artemisa-Calu, D., and Madalina-Girbina, M. (2011). A Story about IAS/IFRS Implementation in Romania: An Institutional and Structuration theory perspective. Journal of Accounting in Emerging Economies, 1(1), 76-97.

[5] Al Saeed, K. (2006). The Association Between Firm Specific Characteristics and Disclosure: The Case of Saudi Arabia. Managerial Accounting Journal, 21(5), 476-495.

[6] Al-Shammari, B., Brown, P., and Tarca, A. (2008). An Investigation of Compliance with International Account Standards by Listed Companies in the Gulf Co-Operation Council Member States. The International Journal of Accounting, 43(1), 425-447.

[7] Al-Shammari, B. (2011). Factors influencing the extent of mandatory compliance with international financial reporting standards: The case of Kuwaiti listed companies. Journal of International Business and Economics, 11(4), 305-360.

[8] Al-Qahtani, A. (2005). The Development of Accounting Regulation in the GCC. Managerial Auditing Journal, 20(3), 217-226.

[9] Bahrain Economic Indicators, (2013), Central Bank of Bahrain. economic_indicators.htm)

[10] Ballas, A., Skoutela, D., \& Christos, T. (2010). The Relevance of IFRS to an Emerging Market: Evidence from Greece. Managerial Finance, 36(11), 931-948.

[11] Borker, D. (2012). Accounting, Culture, and Emerging Economies: IFRS in the BRIC Countries. Journal of Business and Economics Research, 10(5), 313-322.

[12] Boumediene, E., Boumediene, S., Nafti, O. (2014). Impact of Adopting IAS-IFRS on the Handling of Accounting Data: The Case of France.The Journal of Applied Business Research, 30(4), 1239-1249.

[13] Cairns, D. (1997). IFAC--20 years on. World Accounting Report, $2 . \quad$ Retrieved from http://search.proquest.com/docview/204256361 ?accountid=44 753

[14] Cavalier-Rosa, G., \& L. Tiras, S. (2013). Brazil's Adoption of IFRS: Fertile Ground for Examining Earnings Management. Brazilian Business Review, 10(4), 133-146.

[15] Cooke, T. E., \& Wallace, R. S. O. (1990). Financial disclosure regulation and its environment: A review and further analysis. Journal of Accounting and Public Policy, 9(2), 79-110.

[16] Demir, V., \& Bahadir, O. (2014). An Investigation of Compliance with International Financial Reporting Standards by Listed Companies in Turkey. Accounting and Management Information Systems, 13(1), 4-34.

[17] Desoky, A. M., \& Mousa, G. A. (2014). The Value Relevance and Predictability of IFRS Accounting Information: The Case of GCC Stock Markets. International Journal of Accounting and Financial Reporting, 4(2), 215-235.

[18] Ebrahim, A. (2014). IFRS Compliance and Audit Quality in Developing Countries: The Case of Income Tax Accounting in Egypt. Journal of International Business Research, 13(2), 1937.

[19] Glaum, M., \& Street, D.L. (2003). Compliance with Disclosure Requirements of Germany's New Market: IAS versus US GAAP. Journal of International Financial Management and Accounting, 14(1), 64-100.

[20] Hamdan, A. (2011). The Impact of Company Size, Debt Contracts, and Type of Sector on the Level of Accounting Conservatism: An Empirical Study from Bahrain. International Journal of Business and Management, 6(7), 134146.

[21] Harper, A., Leatherbury, L., Machua, A., \& Phillips, J. (2012). The Impact of Switching to International Financial Reporting Standards on United States Businesses. Journal of International Education Research, 8(4), 467-472.

[22] Hla, D. T., Isa, A. H., \& Shaikh, J. M. (2013). IFRS Compliance and Nonfinancial Information in Annual Reports of Malaysian Firms. IUP Journal of Accounting Research \& Audit Practices, 12(4), 7-24.

[23] Holthausen, R. W. \& Leftwich R. W. (1983). The Economic Consequences of Accounting Choice. Journal of Accounting and Economics, 5(1), 77-117.

[24] Hossain, M., \& Hammami, H. (2009). Voluntary Disclosure in the Annual Reports of an Emerging Country: The Case of Qatar. Advances in Accounting, Incorporating International Advances in Accounting, 25(2), 225-265.

[25] Hussain, M., Islam, M. M., Gunasekaran, A., \& Maskooki, K. (2002). Accounting Standards and Practices of Financial Institutions in GCC countries. Managerial Auditing Journal, 17(7), 350-362.

[26] International Accounting Standard 18: Revenue. (2009). European Commission. (http://ec.europa.eu/internal_market/accounting/docs/consolid ated/ias18_en.pdf)

[27] Juhmani, O. (2012). Ownership Structure and Corporate Voluntary Disclosure: Evidence from Bahrain. International Journal of Accounting and Financial Reporting, 3(2), 133-148.

[28] Joshi, P. L., Al-Mudhahki, J. (2013). Empirical Study of Compliance with International Accounting Standards (IAS-1) by Stock Exchange Listed Companies in Bahrain. Journal of Financial Management and Analysis, 26(2), 44-55.

[29] Joshi, P. L., Ramadhan, S. (2002). The adoption of international accounting standards by small and closely held companies: evidence from Bahrain. The International Journal of Accounting, 37(4), 429-440. 
[30] Abdel Karim, R. A. (2001). International accounting harmonization, banking regulation, and islamic banks. The International Journal of Accounting, 36(2), 169-193.

[31] Kelly, M. (2014). IAS18 Revenue: Current Accounting Treatment and New Developments. CPA Ireland. (http://www.cpaireland.ie/students/study-support/professional1/p1-corporate-reporting/p1-corporate-reporting-articles)

[32] Kingdom of Bahrain Economic Year Book 2013, Bahrain Economic Development Board. (http://www.bahrainedb.com/en/EDBDocuments/BahrainEconomic-Yearbook.pdf)

[33] Mardini, G. H. (2013). Narrative disclosure under IAS 14R and IFRS 8 by Qatar listed companies. GSTF International Journal on Business Review, (2(3), 9-14.

[34] Mande, B. (2014). Emerging nations and financial reporting complex: A case of IFRS adoption in Nigeria. Journal of finance, Accounting, and Management, 5(2), 1-23.

[35] Rahahleh, M. Y., Siam, W. Z. (2009). The importance of applying the International Accounting Standard IAS 32 and its effect on financial statement presentation at Jordanian commercial banks. International Management Review, 5(1), 20-36,105.

[36] Ramanna, K., \& Sletten, E. (2010). Why do countries adopt international financial reporting standards?. Rochester: Social Science Research Network. doi:http://dx.doi.org/10.2139/ssrn.1460763

[37] Sarea, A., and Hanefah, H. (2013). The need of accounting standards for Islamic financial institutions. International Management Review, 9(2), 50-59, 95.

[38] Street, D. L., and Bryant, S. M. (2000). Disclosure level and compliance with IASs: A comparison of companies with and without U.S. listings and filings. The International Journal of Accounting, 35(3), 305-329.

[39] Street, D. L., and Gray, S. J. (2001). Observance of international accounting standards: Factors explaining noncompliance by companies referring to the use of IAS. An ACCA Research Monograph, 74.

[40] Sucuahi, W. T. (2013). Firm size as predictor of compliance to International Financial Reporting Standards: IFRS 8. International Journal of Business and Management, 6(1), 4560 .

[41] Tait, D. (2005). Accounting, auditing, and taxation in Bahrain. Doing Business with Bahrain: A Guide to Investment Opportunities and Business Practice, 20(3), 222-229.

[42] Tower, G., Hancock, P., \& Taplin, R. H. (1999). A Regional Study of Listed Companies' compliance with International Accounting Standards. Accounting Forum, Vol.23, No.3.

[43] Watts, R., \& Zimmerman, J. (1983). Agency problems, auditing and theory of the firm: Some evidence. Journal of Law and Economics, 26(3), 613-633.

[44] Yiadom, E., and Atsunyo, W. (2014). Compliance with International Financial Reporting Standards by Listed Companies in Ghana. International Journal of Business and Management, 9(10), 87-100.

\section{Biography}

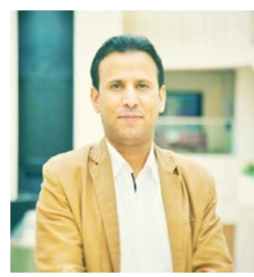

Dr Adel Mohammed Sarea received his PhD from Islamic Science University of Malaysia in 2011. Dr Adel joined Ahlia University of Bahrain in January, 2012 as Assistant Professor of Accounting, Accounting and Economics Department, College of Business and Finance. He Conducted research in the area of Accounting for Islamic Financial Institutions, International Accounting Standards, Financial Reporting, Earning Quality, Earning Management, Intellectual Capital and Accounting Education and published in the journals of repute. He is appointed as a recognized $\mathrm{PhD}$ supervisor by Brunel University (UK). He also serves as a member of the editorial boards in a number of international journals. Currently he is the Director of MBA program. He can be reached at asarea@ahlia.edu.bh / Adelsarea@hotmail.com Accounting and Economics Department, College of Business and Finance, Ahlia University, Manama, Kingdom of Bahrain.

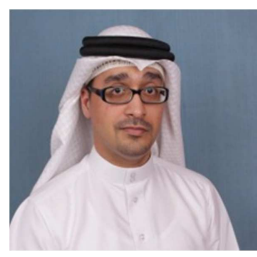

Isa Adnan Budaraj received his Bachelor's degree in Banking and Finance from Ahlia University in 2010, and his MBA in 2015, also from Ahlia University. Isa is currently employed at the National Bank of Bahrain, Bahrain's first established bank, as an Executive Trainee. The position is granted to those with potential to hold leadership roles within the bank in the future. He can be reached at essabudraj@gmail.com. 